\title{
Risk Behaviour for HIV Transmission in Attenders on Methadone Maintenance
}

\author{
H. Williams, E. Mullan, J. J. O'Connor, *A. Kinsella \\ Drug Treatment Centre, Trinity Court, 30-31 Pearse Street, Dublin 2; and *Department of Mathematics, \\ D.I.T., Kevin Street, Dublin 2.
}

Summary

Sixty-nine opiate addicts on methadone maintenance programmes at the Drug Treatment Centre were interviewed, all meet DSM. 3 criteria for opioid dependency. Most were young, poorly educated, unemployed and had involvement with both police and prison. Drug abuse started at a young age, all had injected drugs, heroin being the most widely abused opiate. Forty-eight $(70 \%)$ were HIV (Human Immunodeficiency Virus) positive. Since diagnosis these individuals had made significant changes in their injecting practices and sexual behaviour. However, despite this positive change, there remained a high level of at risk behaviour for further HIV transmission.

\section{Introduction}

The opiate epidemic in Dublin ${ }^{1}$, first reported in the early and mid eighties, remains a major problem and this has been reflected in the large number of attenders at the Drug Treatment Centre. In 1982-83, a study carried out by the Medico Social Research Board ${ }^{2}$ found that in the north inner city area the prevalence of heroin abuse was 10\% in the 15-24 years age group.

The high risk of HIV (Human Immunodeficiency Virus) infection among injecting drug users who share equipment is well known as is their potential to act as a bridging group for further spread of the virus to the general community ${ }^{3}$. It highlights the importance of continued efforts to control the spread of drug abuse, the need for wide ranging treatment facilities for those addicts seeking treatment and the necessity to encourage those addicts who continue to use drugs to act more responsibly and alter their at-risk behaviour. A recent report by Robertson et al. ${ }^{4}$, suggests that injecting addicts, especially those who are HIV seropositive, are indeed receptive to advice concerning at-risk behaviour and capable of subsequent behavioural change.

The HIV seropositive prevalence rates among different groups of intravenous drug abusers shows much geographical variation. High rates (seroprevalence of $50 \%$ of greater are found in regions of Southern Italy and Spain, while much lower rates (seroprevalence of less than $20 \%$ are reported from Denmark and Sweden 5 . In the United Kingdom particularly high rates are found among drug users in Edinburgh compared with Glasgow and London ${ }^{6}$. By the end of 1988, 1788 individuals in Scotland were HIV positive and of these 55\% were drug users mainly concentrated in Edinburgh $^{7}$. By comparison in the Republic of Ireland by December 1988, 794 people were HIV positive, of these $436(54.9 \%)$ were intravenous drug users and 53 were children born to drug abusers. In total 3107 intravenous drug users were tested giving a seroprevalence rate for IV drug users of 14\% (436/3107) (Prof. I. Hillary, Department of Medical Microbiology, University College Dublin, personal communication). It is likely, however, that true seroprevalence is higher given that many IV drug users have not been tested and that a percentage of those previously found to be HIV

This article is a reproduction of that published in: Irish Journal of Medical Science, 159(5), May 1990, pp. 141-144. Pagination may not match that of the original. 
negative many subsequently seroconvert, especially if they continue to share equipment. Multiple testing by individuals may also affect seroprevalance rates.

In the present study we sought to investigate the extent of at-risk behaviour for HIV transmission among those known to be sero-positive and measure the degree (if any) of positive change in such behaviour.

\section{Method}

All those patients attending the Drug Treatment Centre at the start of November 1988 who were receiving methadone maintenance programmes were selected for possible inclusion in the study $(\mathrm{N}=70)$. Patients receiving this programme are in general those addicts who, despite repeated detoxification, fail to remain abstinent and/or those addicts who experience the additional difficulty of coping with the knowledge of being seropositive for HIV. Pregnant opiate addicts are maintained on a relatively low dose methadone regime during pregnancy. The goal of eventually becoming drug free is promoted in all patients.

Patients attend the clinic on a daily basis for methadone (Physeptone-Linctus - average dosage 30mg daily) and for supervised urinalysis. Such patients participated in regular group therapy, occupational therapy and receive individual counselling. Family members attend support groups and special facilities are available for addicted mothers including a crèche for their children.

Of the 70 patients selected for inclusion and asked to participate in the study, none refused. One patient was subsequently excluded as he stopped attending the clinic. The study sample therefore comprised of 69 patients ( 38 males and 31 females), all meet DSM 3 criteria $^{8}$ for opioid dependency. A questionnaire was formulated to gather standardised information on social and demographic characteristics, relevant clinical details and drug history.

The questionnaire also included questions on sexual and needle sharing practices in order to elucidate the level of at-risk behaviour for HIV transmission. The questionnaires were completed by one of the authors (HW) during individual interviews with the patients. Where necessary, the information was validated and additional information gathered by reference to the patients' clinical records. The study was carried out in November and December 1988. The data was tabulated using a computer programme. In the case of one patient, it was found to be incomplete. The completed parts of this questionnaire were included in the overall statistical analysis.

\section{Subjects}

The characteristics of the sample were as follows:

The mean age was 27.8 years (S.D. 4.9). Age distribution ranged from 18-39 years.

38 were males $(55 \%) .31$ were females $(45 \%)$. $(\mathrm{N}=69)$.

22 were single $(32 \%) .11$ married (16\%), 7 married but separated $(10 \%)$ and 29 were cohabitating with a partner $42 \%)$.

$33(48 \%)$ of the sample reported having a partner who also abused drugs. The majority, 59 $(85 \%)$ lived in local authority housing with the remaining living in private or rented accommodation.

The mean number of children for the group as a whole was 2 (S.D. 1.4). 14 had no children $(18 \%)$.

24 had a father with alcoholism (35\%), while 7 reported psychiatric illness in the father (10\%). 9 had mothers with an alcohol problem (13\%) and 13 had a mother with psychiatric illness $(19 \%)$.

With regard to siblings, most patients came from large families, the mean number of siblings being six. 34 had at least one sibling (49\%) with a history of drug abuse.

The mean age on leaving school was 13.9 years (S.D. 1.6). 49 had no formal educational qualifications (71\%).

61 were unemployed (88\%) during the two years prior to the interview.

$51(74 \%)$ had served prison sentences and of these 37 (73\%) admitted to injecting drugs while in prison on at least one occasion. A history of jaundice or hepatitis was reported by $41(59 \%)$ 
of the sample, $46(67 \%)$ reported skin infections, or abscesses, while $33(48 \%)$ reported non intentional overdose.

The mean age of first drug use (excluding alcohol and tobacco) was 15.8 years (S.D. 3.6). 62 of the sample had used some drugs by 18 years of age $(90 \%)$.

Cannabis was the first drug used by 33 of the sample (48\%). Opiates were used by 22 (32\%), LSD by $4(6 \%)$. Cocaine, Benzodiazepines and cough preparations by $3(4 \%)$ respectively, and Barbiturates by $1(1 \%)$.

Mean age of onset of first dependency defined as continuous daily use for one month or more was 18.8 years (S.D. 3.6), range 12-33 years.

The mean age of first presentation for treatment was 20.5 years. Prior to being commenced on the maintenance programme, all had used more than one drug, mainly opiates. Heroin was used by $67(97 \%)$ of the sample, $62(90 \%)$ reporting it as the drug they used most frequently.

\section{Results}

Current HIV status : Forty-eight (70\%) were sero-positive, 16 (23\%) were sero-negative and HIV status was unknown in $5(7 \%)$. The mean duration of time since diagnosis was 28.5 months, range 2-39 months (S.D. 10.2). Eighteen individuals (26\%) reported that their partner was sero-positive, $23(32 \%)$ had partners who were sero-negative and $22 \%$ had partners whose status was unknown (20\%) had no regular partner).

Those who are sero-positive $(\mathrm{N}=48)$ were asked about their needle sharing and sexual activities since becoming sero-positive. They were asked about the same behaviour prior to seroconversion.

Sexual behaviour: Since becoming sero-positive, 42 individuals (88\%) remained sexually active, the majority, $27(64 \%)$ with one partner. Seven (17\%) admitted that they did not always inform the sexual partner(s) of their HIV status. Of those who were sero-positive and sexually active (42/48), 15 (36\%) denied using condoms, $11(26 \%)$ said they use them sometimes and 16 $(38 \%)$ claimed they used condoms always. Prior to sero-conversion, all but one patient $(98 \%$, $47 / 48)$ were sexually active. Forty-one (87\%) claimed that they never used condoms, $5(11 \%)$ used condoms sometimes, with only one (2\%) always. There were 15 female patients who were seropositive and of these, eight had become pregnant since sero-conversion.

Equipment sharing activity: Despite being sero-positive, 30 patients $(63 \%)$ admitted to having continued to share injecting equipment. Of these, $6(20 \%)$ said they did so regularly (more than once per month), with $24(80 \%)$ only sharing occasionally (less than once per month). Eleven (37\%) said they limited sharing to one other person while $19(63 \%)$ had shared with more than one other person. Prior to becoming sero-positive, almost all $(47 / 48,98 \%)$ had shared needles, 41 (87\%) did so frequently (more than once per month) and $42(89 \%)$ admitted to having shared with more than one other person.

Evidence of change was calculated by comparing behaviour prior to and subsequent to the patient being diagnosed sero-positive. The changes in the percentages found before and after diagnosis were analysed using the McNemar test for matched pairs data ${ }^{9}$. Results are summarized in Table I.

\section{Discussion}

A number of recent papers ${ }^{4,10,11,12}$ have reported on risk behaviour for HIV infection among different groups of injecting users and commented on changes in such behaviour as a result of AIDS awareness. Hart et $\mathrm{al}^{10}$ reported that $62 \%$ of their sample of London addicts had made changes in their drug use (reduced sharing, reduced injecting, etc.) However, 69\% had made no changes in their sexual behaviour. Stimson et $\mathrm{al}^{11}$ reporting on attenders to needle exchange programmes in the U.K., found that the majority had made changes in injecting practices but again changes in sexual behaviour 
TABLE I

Behavioural change following diagnosis of HIV infection.

$\mathrm{N}=48$

\begin{tabular}{lccr}
\hline Number of Patients & Before & After & $\mathrm{X}^{2}$ Test \\
\hline Sharing needles & $98 \%$ & $63 \%$ & $(\mathrm{P}<0.001)$ \\
Sharing frequently & $87 \%$ & $20 \%$ & $(\mathrm{P}<0.001)$ \\
Sharing with 2 or more others & $89 \%$ & $63 \%$ & $(\mathrm{P}<0.01)$ \\
Using condoms & $13 \%$ & $64 \%$ & $(\mathrm{P}<0.001$ \\
\hline
\end{tabular}

were less common. In another sample of London addicts, Power et $\mathrm{al}^{12}$ found that $54 \%$ had substantially reduced their risk behaviour. Interestingly, of the six people who were HIV positive in that study, all had altered behaviour since having been tested. The study did not, however, address the sexual practices of the clients. In Edinburgh, Robertson et $\mathrm{al}^{4}$ reported significant changes in all aspects of drug use and sexual behaviour in 49 intravenous heroin addicts. Changes were most marked in those infected with HIV. Like the present study, their clients had a high rate of seropositivity $(59 \%)$.

In the present study, we look specifically at those patients known to be sero-positive $(\mathrm{N}=48)$ and investigated whether they had altered their behaviour as a result of being infected. Results were encouraging. The number of addicts sharing injecting equipment reduced from 47 $(98 \%)$ to $30(63 \%)$. Of those who continued to share after diagnosis, only $6(20 \%)$ did so regularly. Forty-one $(87 \%)$ had shared regularly prior to diagnosis. We also found a significant reduction in the number of addicts sharing with two or more others, $42(89 \%)$ to $19(63 \%)$. Prior to diagnosis 47 $(98 \%)$ had been sexually active and only $6(13 \%)$ ever used condoms. Forty-two patients $(88 \%)$ remained sexually active after diagnosis but the number using condoms had increased significantly to $27(64 \%)$. Our findings support the results of previous work ${ }^{4,10,11,12}$ and suggest that our seropositive addicts, like other groups of addicts, are capable of altering at risk behaviour for further HIV infection.

However, a number of disturbing facts also emerged from the study and merit attention. Despite being sero-positive 30 individuals $(63 \%)$ had continued to share injecting equipment (even if at a reduced risk level) and more than one-third who remained sexually active, did not use condoms. The fact that these individuals continue to facilitate further transmission of the virus is worrying. It was beyond the scope of the present study to enquire into the reasons why these individuals were unable/unwilling to alter at risk behaviour. Some did claim that they restricted such behaviour to others known to be sero-positive also. Another cause for concern was that since sero-conversion, eight out of fifteen sero-positive females (53\%) had become pregnant. Indeed, in a previous report ${ }^{13}$ from our centre it was found that $43 \%$ of pregnant sero-positive addicts subsequently became pregnant again. This was despite the fact that pregnant sero-positive addicts attend a special programme and receive repeated counselling with regard to the risks of pregnancy, to both mother and child. Over a quarter $(26 \%)$ of the sample had a partner who was also seropositive. It is uncertain whether these partners had become infected through their own injecting practices (48\% of the addicts had partners who also abused drugs) or whether infection was a result of sexual transmission.

Of all those interviewed ( $\mathrm{N}=69), 51(74 \%)$ had served prison sentences and of those, 37 (73\%) admitted to having injected drugs while in custody. Given the high level of HIV infection in the group and the likelihood of illicit sharing while in prison, the present findings support the concern expressed by others regarding the potential for the spread of HIV infection in prisons. ${ }^{14}$

The validity of self-reported information from addicts is often questioned. Benson et al ${ }^{15}$ however, found that drug addicts gave an unexpectedly high degree of truthful information. In the present study, information received during interview corresponded closely with data accumulated in the patients' clinical records. 
We do not claim that the group studied is representative of all opiate abusers in Dublin. The sample was drawn from

TABLE II

Comparison with other studies of opiate abuse in Dublin.

\begin{tabular}{|c|c|c|c|c|c|}
\hline Author: & $\begin{array}{c}\text { Dean, Bradshaw } \\
\text { Lavelle } \\
(1983)\end{array}$ & $\begin{array}{c}\text { O'Kelly } \\
\text { et al } \\
(1986)\end{array}$ & $\begin{array}{l}\text { O’Connor } \\
\text { et al } \\
(1986)\end{array}$ & $\begin{array}{l}\text { O’Connor } \\
\text { et al } \\
(1988)\end{array}$ & $\begin{array}{l}\text { Williams } \\
\text { et al } \\
(1990)\end{array}$ \\
\hline Setting: & $\begin{array}{l}\text { Inner City } \\
\text { Area }\end{array}$ & $\begin{array}{l}\text { Inner City } \\
\text { General } \\
\text { Practice }\end{array}$ & $\begin{array}{l}\text { City A \& E } \\
\text { Departments }\end{array}$ & $\begin{array}{l}\text { Pregnant } \\
\text { Addicts. } \\
\text { Drug Treat- } \\
\text { ment Centre }\end{array}$ & $\begin{array}{l}\text { Maintenance } \\
\text { Programme. } \\
\text { Drug Treat- } \\
\text { ment Centre }\end{array}$ \\
\hline $\begin{array}{l}\text { Sample Size: } \\
\text { Age: }\end{array}$ & $\begin{array}{c}88 \\
15-24 y\end{array}$ & $\begin{array}{l}67 \\
-\end{array}$ & $\begin{array}{c}73 \\
26 y(\text { mean }) \\
(14-50 y)\end{array}$ & $\begin{array}{c}45 \\
23.3 y(\text { mean }) \\
(16-34 y)\end{array}$ & $\begin{array}{c}69 \\
27.8 \mathrm{y}(\text { mean }) \\
(18-39 y)\end{array}$ \\
\hline $\begin{array}{l}\text { Local Authority } \\
\text { Housing: }\end{array}$ & - & $88 \%$ & - & $95 \%$ & $85 \%$ \\
\hline $\begin{array}{l}\text { Family history } \\
\text { of Alcoholism: }\end{array}$ & $34 \%$ & $40 \%$ & - & $50 \%$ & $35 \%$ \\
\hline $\begin{array}{l}\text { Poor Educational } \\
\text { Attainment: }\end{array}$ & $\begin{array}{l}67 \% \\
\text { (left school } \\
\text { before } 15 \mathrm{y} \\
\text { of age } \\
95 \% \\
\text { (no formal } \\
\text { examinations) }\end{array}$ & $95 \%$ & - & $70 \%$ & $65 \%$ \\
\hline $\begin{array}{l}\text { Unemployed: } \\
\text { Criminal History }\end{array}$ & $95 \%$ & $98 \%$ & $63 \%$ & $100 \%$ & $87 \%$ \\
\hline $\begin{array}{l}\text { Served Prison } \\
\text { Sentence: }\end{array}$ & $64 \%$ & $40 \%$ & - & $95 \%$ & $74 \%$ \\
\hline $\begin{array}{l}\text { Injected Drugs: } \\
\text { Early Onset }\end{array}$ & $92 \%$ & $100 \%$ & $59 \%$ & $100 \%$ & $100 \%$ \\
\hline of Abuse: & $\begin{array}{l}75 \% \\
\text { (used Heroin } \\
\text { by } 19 y \text { ) }\end{array}$ & $\begin{array}{c}57 \% \\
\text { (used Heroin } \\
\text { by } 19 y \text { ) }\end{array}$ & $\begin{array}{l}- \\
-\end{array}$ & $\begin{array}{l}\text { First used } \\
\text { drugs } 16.5 y \\
\text { (mean) } \\
47 \% \text { first } \\
\text { used Heroin }\end{array}$ & $\begin{array}{c}60 \% \\
\text { (Opiate } \\
\text { dependent } \\
\text { by } 18 y)\end{array}$ \\
\hline
\end{tabular}

Those addicts attending our clinic and receiving methadone maintenance programmes. This represents a group of addicts who in general have failed previous attempts at detoxification and who have a long history of attendance (albeit punctuated by episodes of relapse and periods in prison). Despite these and other limitations (definitions, methods used etc.) many of their general characteristics are comparable with other reports on opiate abuse in Dublin ${ }^{16,17,18}$, (Table II). The present study limited its investigation of behavioural change to those known to be HIV seropositive. We are unable to say at present whether similar patterns of change can be applied to those individuals who were sero-negative (or whose status was unknown). It is an area that would merit further research.

In summary, our attenders represent a young, unemployed socially deprived group. They come from disturbed backgrounds and are poorly educated. There is a long history of illicit drug abuse. All injected opiates intravenously, mainly heroin. Since diagnosis those who are HIV seropositive $(\mathrm{N}=48)$ had made significant alterations in their at risk behaviour for HIV transmission. We however, see no case for complacency. There remains a large number of sero-positive individuals who continue to act irresponsibly and in doing so, put others at risk of infection. It appears that at risk behaviour has been reduced but not eliminated. 


\section{Acknowledgements}

We would like to thank Siobhan Fisher for her help in typing the manuscript.

\section{References}

1. Dean, G., Kelly, M., O'Hare, A., Kelly, G., O'Connor, A. The opiate epidemic in Dublin 1979-83. Irish Medical Journal 1985: 78, 107-10.

2. Dean, G., Bradshaw, J. S., Lavelle, P. Drug misuse in Ireland 1982-83. The Medico-Social Research Board, Dublin.

3. Moss, A.R. AIDS and intravenous drug use: The real heterosexual epidemic. British Medical Journal. 1987: 294, 389-390.

4. Robertson, J.R., Skidmore, C.A., Roberts, J. J. K. HIV infection in intravenous drug abusers: A follow up study indicating changes in risk taking behaviour. British Journal of addiction. 1988: 83, 387-391.

5. Adler, M. W. Epidemiology of HIV infection. Journal of the Royal College of Physicians of London. 1988: 22, 133-135.

6. Robertson, J. R., Bucknall, A. B. V., Wiggins, P. Regional variations in HIV antibody seropositivity in British intravenous drug users. Lancet ii. 1986: 1435-1436.

7. Anonymous. Scottish AIDS. (Editorial). British Medical Journal. 1989: 298, 141-142.

8. American Psychiatric Association. Diagnostic and statistical manual of mental disorders. Third Edition. Washington, D.C., A.P.A. 1980.

9. $\quad$ Fleiss, J. L. (Ed.). Statistical Methods for Rates and Proportions. J. Wiley, 1973.

10. Hart, J. G., Sonnex, C., Petherick, A., Johnson, A. M., Feinmann, C., Alder, M. W. Risk behaviours for HIV infection among injecting drug users attending a drug dependency clinic. British Medical Journal. 1989: 298, 1081-1083.

11. Stimson, G. V., Donoghue, M., Alldritt, L. Dolan, K. HIV transmission risk behaviour of clients attending syringe-exchange schemes in England and Scotland. British Journal of Addiction. 1988: 83, 1449-1455.

12. Power, R., Hartnoll, R., Daviaud, E. Drug injecting AIDS and risk behaviour: Potential for change and intervention strategies. British Journal of Addiction. 1988: 83, 649-654.

13. O'Connor, J. J., Stafford-Johnson, S. AIDS and intravenous drug abuse. (Letter). British Journal of Addiction, 1987: 82, 813-814.

14. McMillan, A. HIV in prisons. British Medical Journal. 1988: 297, 873-874.

15. Benson, G., Holmberg. M. B. Validity of questionnaires in populations studies on drug use. Acta Psychiata. Scand. 1985: 71, 9-11.

16. O'Kelly, F. D., O’Doherty, K., Bury, G., O'Callaghan, E. Heroin abuse in an Inner City practice. Irish Medical Journal. 1986: 79, 85-87.

17. O’Connor, J. J., Stafford-Johnson, S., Kelly, M., Byers, G. Attendance for drug misuse to Dublin Accident and Emergency Departments. Irish Medical Journal. 1986: 79, 328-329.

18. O'Connor, J. J., Stafford-Johnson, S., Kelly, M. G. A review of the characteristics and treatment progress of 45 pregnant opiate addicts. Irish Journal of Medical Science. 1988: $157,146-149$. 